\title{
Problems of Irrigation in Developing Countries
}

\author{
By Phillip Z. Kirpich, ${ }^{1}$ Dorota Z. Haman, ${ }^{2}$ and Stuart W. Styles ${ }^{3}$
}

\begin{abstract}
This paper describes the crucial importance of irrigated agriculture to developing countries and to the world as a whole. This is followed by a summary of key problems that restrict and diminish the benefits of irrigated agriculture. Solution of these problems will above all require a holistic approach and will require changes in the institutions involved. These institutions include those of the developing countries, of the developed countries that provide aid, and of the international financing and technical-assistance agencies. Engineers in the developed countries have had, and will continue to have, a leading role but will need some redirection. ASCE could provide valuable assistance in this redirection.
\end{abstract}

\section{INTRODUCTION}

The term "developing countries" is interchangeable with "lesser developed countries," also referred to as LDCs. In 1995, when the countries of the world numbered 133, the World Bank placed them into four categories according to Gross National Product (GNP) per capita. In 1995 these were: low, $\$ 80$ to $\$ 750$; lower middle, $\$ 760$ to $\$ 3,020$; upper middle, $\$ 3,050$ to $\$ 9,500$; and high, over $\$ 9,500$ (World 1997). (The GNP per capita of the U.S. in 1995 was $\$ 26,980$.) If developing countries are designated as those in the two lowest categories, in 1995 there were 90 such countries, with GNP ranging from about $\$ 80$ to $\$ 3,020$, and their population was about 4.8 billion, or $84 \%$ of the world population of 5.7 billion.

In most of these countries, an adequate diet - and therefore expanded food production - is a pressing objective; irrigation and drainage (I\&D) are keys to meeting this objective. There are fundamental differences between I\&D in the developing countries and I\&D in the developed countries - a fact that the professional planners concerned need to understand if they expect to participate effectively in this growing and increasingly crucial field, namely, the improvement of irrigated agriculture in developing countries.

\section{WORLD POPULATION AND AGRICULTURAL PRODUCTION}

From Fig. 1 note the doubling of the world's population between now and 2050. Almost all of this increase will be in the developing countries. Feeding this population will become increasingly difficult because limits on food production are being approached in many of these countries.

Leading authorities - among them, Brown (1998), Falkenmark and Widstrand (1992), Postel (1996), and "Food", (1996) - have described probable future trends with respect to the demand and supply of food. Their general consensus is that there is no immediate threat of a global food shortage, but that it is urgent to institute planning to avoid shortages in several key regions, all of which are in the developing countries. These include India, Pakistan, China, Mexico, Brazil, the Middle East and North Africa, and much of Sub-Saharan Africa.

${ }^{1}$ World Bank Retiree and Consulting Engr., 20 Island Ave., \#1418, Miami Beach, FL 33139-1315.

${ }^{2}$ Assoc. Prof., Agric. Engrg. Dept., Univ. of Florida, Gainesville, FL 32611.

Asst. Prof., Agric. Engrg. Dept., California Polytechnic State Univ., San Luis Obispo, CA 93407.
The concerns of the consensus, which appear to the writers to be well founded, may be summarized as follows:

- Population increases plus the desire for improved diets (more livestock products) will greatly raise the global demand for grains. A case in point is China, whose grain production is presently reaching limits and is expected to decline substantially in the coming decades (Fig. 2). Concurrently, China's consumption of grain is likely to almost double in the next 40 years as the population rises and as people demand higher living standards including more meat, much of it derived from grain. (World consumption of meat increased from 44 million metric tons in 1950 to 200 million metric tons in 1995.) According to one forecaster (Brown 1995), China's shortfall in grain may reach 210 million tons by 2010 and 420 million tons by 2030 ; other analysts (Huang et al. 1997) are hopeful that China's grain imports may not reach quite that high. Similar shortfalls are likely for India.

- The global output of grain rose greatly during the $1960 \mathrm{~s}$ and $1970 \mathrm{~s}$, but there has been little or no rise since 1990 . World grain prices soared in 1995 and may double by 2010 according to the Japanese Ministry of Agriculture (Brown 1997).

- Trends in recent decades have been unfavorable with respect to world grain production. There has been a drop in grainland per person, caused by growing urbanization and deterioration of agricultural land, and a decrease since 1990 in fertilizer use, the latter due to the fact that the increased yield due to its application has become too small to be profitable (Fig. 3).

- Production from ocean fisheries has reached natural limits. Curtailment is being practiced now through international agreement in order to prevent deterioration and to preserve, at least, the natural limits of fish production. There is scope for expansion of aquaculture, which, however, requires scarce and costly grain.

- Water scarcity is having a negative effect on agricultural output. Overpumping of several major aquifers is occurring, among them those of the Punjab of India and Pakistan, North China, Northwest Mexico, and the Ogallala in the United States. The rapid urbanization taking place in most developing countries will increase competition for scarce water and thereby further reduce its availability for agriculture.

- Many irrigation projects are performing poorly with respect to water distribution.

- Other water-related negative effects are being caused by salinization, pollution, soil erosion, and flooding.

- Other than water, serious impediments to agricultural production in the developing countries are resulting from fragmentation of landholdings, poor land management, and bad macroeconomic policies with respect to land tenure, land taxation, subsidies, and export and import taxes. 


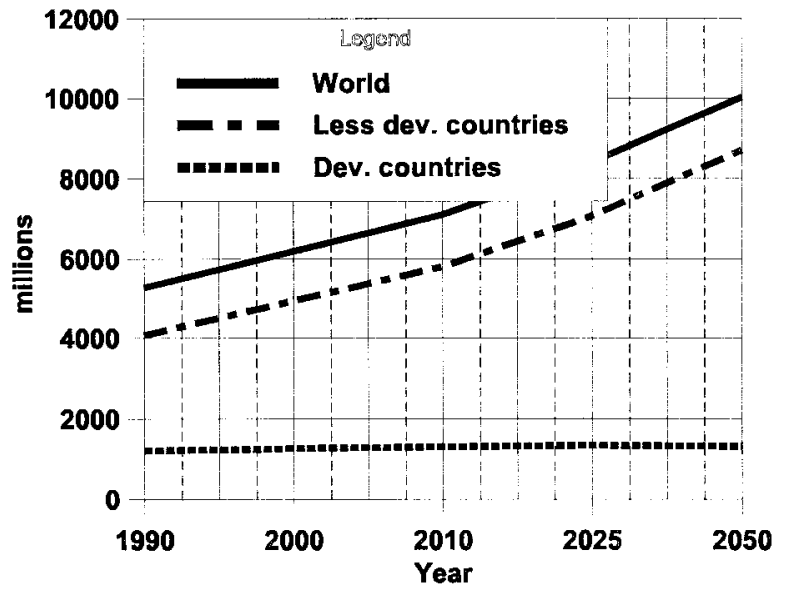

FIG. 1. World Population ("Feeding" 1994)

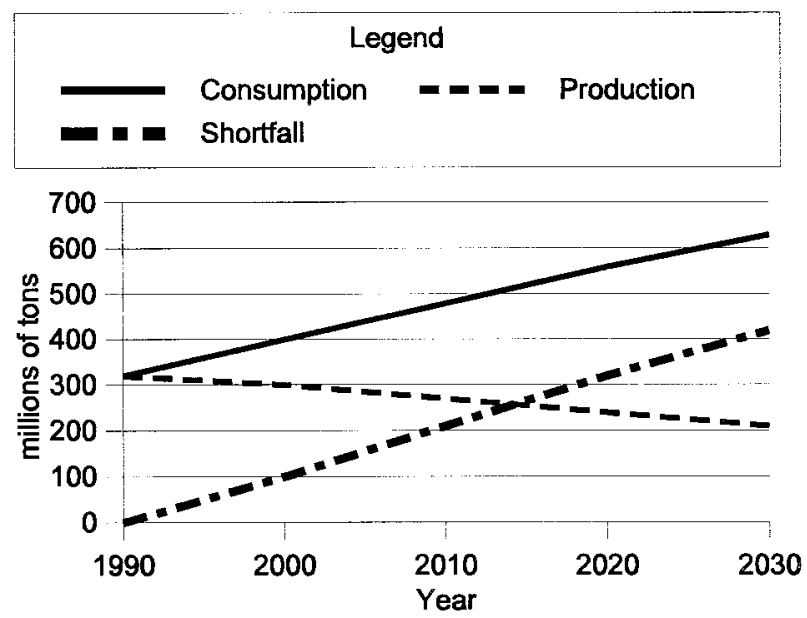

FIG. 2. Grain in China: Production, Consumption, and Shortfall [Source: U.S. Department of Agriculture, Census Bureau (Brown 1995)]

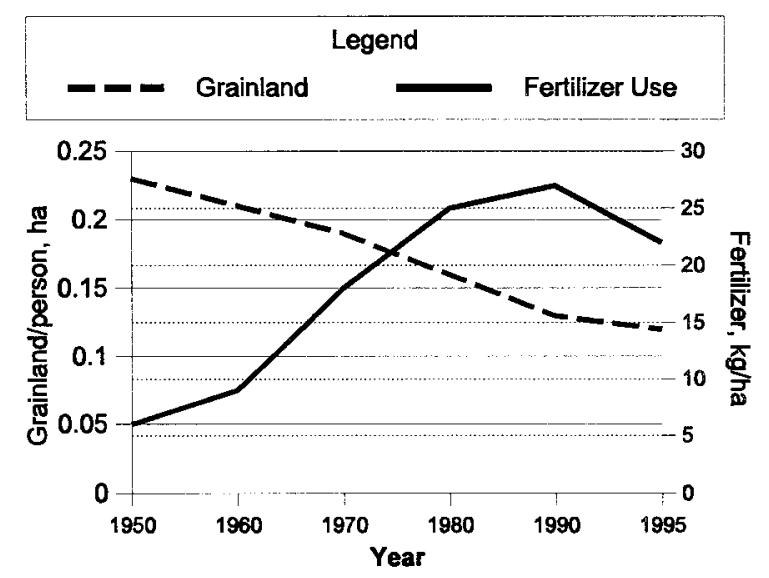

FIG. 3. World Fertilizer Use and Grainland Per Person [Source: U.S. Department of Agriculture, Food and Agricultural Organization of the United Nations (Brown 1995)]

\section{CRUCIAL IMPORTANCE OF IRRIGATED AGRICULTURE}

Arable land on the planet, totaling about 1.5 billion ha, is almost fully utilized. The one-sixth that is in the irrigated sector, about 250 million ha, will have to be the main supplier of the increased demand, but its output will have to be greatly increased. That means squeezing more crop yield from the available water.

Except for the miniscule amount of fresh water derived from

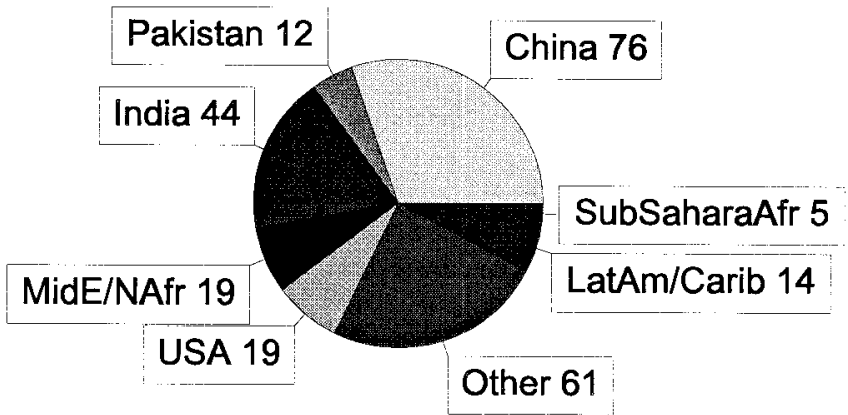

FIG. 4. Irrigated Land Areas in the World in Millions of Hectares

the seas through desalination, the volume of fresh water available for human use equals the runoff on the land from natural rainfall. Hydrologists have made a sufficiently reliable estimate of the average annual global rainfall and of the runoff on land, termed renewable fresh water supply on land (RFWS LAND ), estimated at $40,000 \mathrm{~km}^{3}$ annually. Much land, as in the Amazon rainforest, is inaccessible. Hydrologists have estimated the accessible runoff (AR) to be about $12,500 \mathrm{~km}^{3}$. Of the latter, humanity now uses 54\% (Postel et al. 1996).

In examining the question of available water, one must of course consider not only the global but also the regional amounts, bearing in mind that water can only in exceptional cases be transported economically more than a few hundred kilometers. The key regions mentioned earlier as being subject to risk of food shortage are also those with growing water shortages. These regions will need detailed studies by hydrologists for determination of the available water in each case. Concurrently, economic studies will be needed to ascertain, in each case: (1) To what extent can crops presently grown be replaced by low-water-demand and/or higher-value crops? and (2) how much food, especially grain, should be imported?

Storage of flood runoff, aimed at increasing the AR, is already widely practiced. The development of additional storage by means of dams is not promising since the best sites have already been developed. The only practical alternative is to make better use of the AR through conservation (which includes reduction of per capita domestic use), reduction of losses caused by pollution, and increase of efficiency of irrigation, which is by far the biggest water user.

Fig. 4 shows where the 250 million ha of irrigated land in the world are located. Two-thirds of all irrigated land is in the developing countries, of which three-fourths is in Asia, where, unfortunately, significant reduction of cropland, including irrigated cropland, is taking place due to urbanization and environmental damage.

There is some scope for expansion of I\&D in South and Central America, Mexico, and Sub-Saharan Africa, primarily in tropical-humid zones. Owing to their wetness, such zones must first be drained. Irrigation can come later, as a supplement. Drainage must, however, be carried out with caution so as to reconcile the conflicting demands of agriculture, urban development, transport, and ecosystems. The complications involved are well illustrated by two widely publicized cases: the Everglades in Florida and the Pantanal in Brazil and Bolivia (Wade et al. 1994).

\section{INCREASING OUTPUT OF IRRIGATED AGRICULTURE}

At a workshop organized by the World Bank, leading irrigation experts from the developing countries gave comments on key topics as follows ("Country"' 1992):

- Water losses. In Ethiopia, water losses in some areas reach $40 \%$. In Jordan, the water system experiences heavy 
water losses. In Sudan, the irrigation system is deteriorating. In Mexico, irrigation efficiencies decreased from $65 \%$ in 1988 to $40 \%$ in 1990 . In Egypt, average conveyance losses between the irrigation outlets and the fields are $11 \%$, and those between the outlets and the main canal intakes are $25 \%$. Although it is not clear from these experts' comments whether water losses could be recovered in downstream areas, from what is known with respect to the configuration of the areas in question, it is not believed that such recovery would be significant, except in the case of Egypt.

- Growing salinity. In Iraq, land lost or impaired by salinity is from 20 to $68 \%$. In China, in the Yellow River Valley more than three-quarters of the irrigated land has become saline.

- Nonpayment of water charges. In Egypt, no water charges are collected from farmers, as this is against Islamic precepts. However, in connection with recent physical as well as institutional improvements now under way (pipelines, downstream control on canals, and formation of water user associations), some charges are now being introduced to help pay for the improvements. In Turkey, as agricultural water is heavily subsidized, water-use efficiency suffers. In Thailand, there are laws concerning water charges, but they are not enforced owing to frequent changes in government and lack of political will. In Pakistan, cost recoveries are too meager to cover even the usual O\&M expenses, which results in progressive deterioration of supply systems. Another Pakistani expert, S. S. Kirmani (he was recipient of ASCE's prestigious Tipton Award in 1988, had directed the mammoth Indus Basin Project in Pakistan and later became a high-level official of the World Bank) summarized the current food situation in Pakistan as follows: "Though agricultural production in Pakistan increased dramatically in the Green Revolution years of the sixties, the country was unable to sustain growth and is currently struggling to achieve selfsufficiency in food. Edible imports are skyrocketing ... Pakistan and Thailand are the only two countries in Asia that could export food on a sustainable basis . . . but studies emphasize that realizing this potential lies in improving current water and farm management practices, and agricultural inputs and services.',

- Poor interagency coordination. In Sudan, coordination is poor between two key agencies: one that manages the major canals and secondary canals, and the other that manages tertiary and smaller canals. In Senegal, efforts to reclaim the Senegal River valley have not succeeded owing to lack of central authority at the regional level and excessive, uncoordinated intervention at the national level.

- Neglect of high-value crops. In Egypt, about $30 \%$ of the irrigation supply goes to rice and sugar cane. Although profitable to the farmer who gets free water, these crops are too expensive from a social perspective. In Sudan, the country's self-sufficiency policy leads to mismanagement of water and its use for low-value crops.

- Neglect of pilot projects. In Egypt, urgent steps are needed to establish pilot projects on the use of treated wastewater.

A former president of the International Commission for Irrigation and Drainage (ICID), John Hennessy, in a keynote address in 1992 said: "Irrigation schemes in many parts of the world are known to be performing well below their full potential.... [There is now] wide recognition that deficiencies in management and related institutional problems, rather than the technology of irrigation, were the chief constrainst of poor performance of irrigation systems.",
The question of appropriate technology, an important one for the developing countries, has aroused controversy in recent decades. Some practitioners, as in a publication authored by three World Bank staff members (Plusquellec et al. 1994), favor rapid modernization using up-to-date, sophisticated technology. Others, including the writers, prefer technology that is not oversophisticated, with greater emphasis given to eliminating deficiencies in management and related institutional problems. Caution needs to be exercised in introducing high technology $a$ view shared by another World Bank staff member (Van Tuijl 1993) and by three experts from Israel (Ben-Meir 1989; Melamed 1989; Sne 1989), where the level of sophistication is among the highest in the world. The use of high technology has proved disappointing in many developing countries; concurrently, the realization has grown that correcting deficiencies in management and related institutional problems has become urgent. This view was expressed in a recent review of literature dealing with water user associations ("User'" 1997).

\section{SOME CASES}

The situations in several countries, with which the writers are familiar, are described in the following paragraphs. Space does not allow further descriptions from other countries. One of the writers has described some additional cases in two earlier papers (Kirpich 1987, 1993); he is presently writing a book that describes 30 cases in 25 developing countries.

\section{Bangladesh}

The case of Bangladesh illustrates a frequently occurring situation wherein low-level technology may have advantages and where cooperation among government agencies is essential. Bangladesh has an area about equal to the state of Illinois but with 10 times the population. The annual monsoon flooding followed by a six to seven month dry season make water control a vital matter.

Efforts to date to deal with the cycle of annual flooding followed by drought have given only limited favorable results. The Bangladesh Water Development Board (BWD) has opted for large-scale works (major canals, embankments, and pumping stations) when small-scale works (shallow tubewells and portable, low-lift pumps) are more appropriate at least in the initial stage of development and probably in the long range as well. Yet innumerable foreign consultants have supported the monumentalism of the BWD, causing considerable waste of time and money. Fortunately, the Bangladesh Agricultural Development Corporation, a rival agency, has carried through a nationwide small-scale program for shallow wells and low-lift pumps sited on perennial rivers. This type of development is now reaching a natural limit and will have to be supplemented by some large-scale works, but these should be planned and implemented through joint efforts of the two lead agencies.

The cooperation of local civil authorities is also of great importance, particularly considering that the average landholding in most of Bangladesh is only about 1 ha! The objective of such cooperation should be to secure participation of the local farmers in the following key tasks:

1. Planning of the irrigation distribution system, including the location of gated outlets serving a group of farmers. Owing to the small holdings, gated outlets have to serve a group of as many as 20 farmers. Local people often have good practical suggestions concerning the locations, not only of the gated outlets, but also of the minor canals that serve the gated outlets.

2. Setting procedures for operating and maintaining the farm ditches below the gated outlets. 
3. Arrangements for local farmers to provide labor for O\&M of the minor canals and the gated outlets.

4. Establishment of water user associations that can cooperate with agencies and local banks for agricultural extension, agricultural credit, and marketing of production.

To accomplish these tasks, a program is needed whereby leaders from among the local farmers can be chosen and trained. Efforts for formulation of such a program have been under way for several years with assistance from (mainly foreign) nongovernmental organizations.

\section{Mali}

A project of the United Nations Development Programme and United Nations International Children's Emergency Fund in Mali illustrates the essentiality of local responsibility, particularly when low-level technology is involved. Mali is in the Sahel, a semiarid belt crossing Africa south of the Sahara. The project has assisted villages in obtaining a safe water supply by means of drilled wells equipped with hand pumps. Villagers soon realized that despite back-breaking handcarry (mainly by women), they could irrigate small garden plots to grow crops, mainly for sale in local markets but also to supplement their meager diet. In reviewing the project on behalf of the United Nations, one of the writers spoke at length with the villagers to learn of their problems and preferences. Taking into account available information on ground water, he suggested that the hand pumps be replaced by small diesel or kerosene-driven pumps, which would considerably increase the extent of irrigation while eliminating the back-breaking and time-consuming hauling of water. Village leaders would have to take the responsibility to see that maintenance of the pumps gets done in time. A cadre of mechanics would be trained to take care of other-than-routine maintenance, which could eventually be privatized.

\section{Mexico}

Mexico illustrates how land-tenure practices can impede use of land for intensive, irrigated agriculture. As a neighbor, comember of NAFTA, and beneficiary of loan guarantees, Mexico is of primary interest to the United States. In the early 1970s, with assistance from the World Bank and the United Nations Development Programme, Mexico established an entity under its Ministry of Agriculture and Water Resources entitled Plan Nacional Hidraulico (National Water Plan). A National Water Plan report was issued in 1975 and updated in the years following. This was the first time, as far as the writers know, that a national water plan was prepared by any Latin American country.

The plan, among its conclusions, brought out that further expansion of the irrigation of semiarid land, as in the Pacific Coast and the Central Plateau, may not be feasible owing to limited water resources or high cost. On the other hand, since, under NAFTA, the U.S. market for Mexican vegetables and fruit should be virtually unlimited, much of Mexican irrigation now devoted to grains (corn, wheat, and rice) could be profitably shifted to high-value vegetables and fruits, and there could be a case for further expansion of irrigation in arid-zone lands.

The plan also brought out that the tropical-humid Gulf Coast is greatly underutilized, with generally good soils and ample rainfall usually exceeding $1,500 \mathrm{~mm}$ annually. The first need would be for drainage, sometimes with and sometimes without flood control. Underdevelopment of the Gulf Coast has been mainly due to the prevailing landholding pattern. Ranch owners are enabled by Mexican law to use the land at low carrying capacity per animal. The ranch owners, who exert much political influence, are opposed to government watercontrol projects since, under the law, landholdings in such projects cannot exceed 10 or 20 ha.

\section{INTERNATIONAL WATER CONFLICTS}

The leading ongoing and potentially crucial water conflict is that of the Middle East, about which numerous technical conferences have taken place and papers and books written. A good example of the latter is the book containing papers by 27 leading experts, convened in Cairo, Egypt, in February 1993 (Biswas 1994). From these writings and from personal experience in the region, the authors consider that serious water conflicts such as that in the Middle East are more of a political than a technical nature.

While technical studies and conferences should by all means be continued, little progress in arriving at solutions can be expected in the absence of significant progress in negotiations over the issues among the sovereign nations involved, with the participation of important world political leaders.

\section{SOME STEPS FOR IMPROVEMENT}

From this rather dismal picture, it seems evident that progress in dealing with irrigated agriculture, especially in the developing countries, requires leadership at both national and local levels, a view shared by other observers (Grigg 1996). In the developing countries, the heads of the agencies concerned are usually engineers, but they often lack adequate knowledge of critically important nontechnical factors such as the social structure of the peasant farmers to be benefited, economic constraints at local and national levels, and environmental issues. A holistic approach considering all these factors is essential. That doesn't mean that all problems have to be solved at once, only that they must be considered concurrently.

Many practicioners have long advocated award of a professional degree in engineering only after five, not four, years of university education (Pletta 1989). The additional year would allow time for education in the humanities, which would help develop in engineers the outlook needed to dealholistically with the multiplicity of issues involved with irrigation in developing countries.

Besides a broader education, engineers need to keep up with the literature. This is indeed a problem, considering the volume of written material produced by a large number of organizations. To help solve this problem, some sort of abstracting service is needed that can select and digest significant literature.

Engineers and other experts are eager, as always, to give effective advice to the developing countries on how they can improve performance and output of their irrigated agriculture. However, to do so they must understand-better than in the past that the social and economic characteristics in the developed countries are markedly different from those in the developed countries. From Table 1, which summarizes these characteristics, it is self-evident that planning and implementation in the two groups of countries have to be markedly different. For example, technological innovations like drip irrigation may not be practicable since, in most situations, farm-

TABLE 1. Population: Some Social and Economic Factors

\begin{tabular}{|c|c|c|}
\hline $\begin{array}{c}\text { Factor } \\
(1)\end{array}$ & $\begin{array}{l}\text { Developing } \\
\text { countries } \\
(2)\end{array}$ & $\begin{array}{l}\text { Developed } \\
\text { countries } \\
\text { (3) }\end{array}$ \\
\hline $\begin{array}{l}\text { Gross domestic product per capita } \\
\text { Population in agriculture } \\
\text { Literacy } \\
\text { Rural landholding }\end{array}$ & $\begin{array}{c}\$ 100-\$ 2,000 \\
55-75 \% \\
21-70 \% \\
\text { Typically } 1 \text { ha }\end{array}$ & $\begin{array}{c}\$ 7,000-\$ 28,000 \\
10-40 \% \\
95-100 \% \\
\text { Typically } 20 \text { ha }\end{array}$ \\
\hline
\end{tabular}


ADB - Asian Development Bank

ASCE - American Society of Civil Engineers

AGU - American Geophysical Union

AWRA - American Water Resources Association

FAO - Food and Agriculture Organization of the United Nations

GWP - Global Water Partnership, Stockholm

IADB - InterAmerican Development Bank

IBRD - International Bank for Reconstruction and Development (World Bank)

ICID - International Commission on Irrigation and Drainage

IDRC - International Development Research Centre, Ottawa

IFAD - International fund for Agricultural Development, Rome

IFPRI - International Food Policy Research Institute, Washington

IIMI - International Irrigation Management Institute, Colombo Sri Lanka

ILRI - International Institute for Land Reclamation, Netherlands

IPTRID - International Program for Technical Research in Irrigation and Drainage, Washington

IWRA - International Water Resources Association

MEWIN - Middle East Water Information Network, Philadelphia

OAS - Organization of American States

UNDP - United Nations Development Programme

USAID - U.S. Agency for International Development

USCID - U.S. Committee on Irrigation and Drainage

WWC - World Water Council, Marseilles

Finance

Technical

Technical

Assistance

Publications

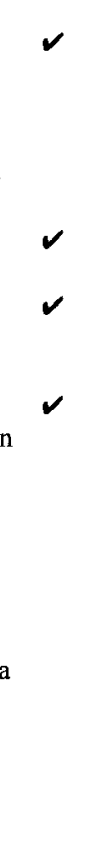

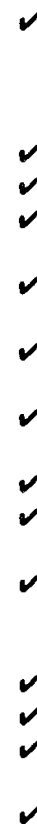

FIG. 5. Organizations Concerned with Irrigation and Drainage in Developing Countries

ers cannot afford to take even small risks and since markets for high-value vegetable and tree crops - best suited for drip irrigation-are often limited.

For the large-scale projects, national policies concerning land tenure, export taxes, or other matters may require adjustment before success can be assured.

\section{FUNDING AGENCIES AND THEIR ROLE}

The national and international technical-assistance and financing agencies, including ASCE (Fig. 5) have important roles. Those that participate in the financing of construction, and sometimes of implementation, are the ones that have the greatest influence. Among these, the World Bank is at the top of the list, but the other international banks also have an important role in terms of volume of lending, especially the Asian Development Bank and the InterAmerican Development Bank.

These banks have at times been criticized by environmentalists for alleged damage to the environment or for social costs resulting from forced resettlement of people, both caused by projects that they helped finance (Frederiksen 1996). Some of the developing countries also resent what they consider the disproportionate voting rights of the wealthy countries on the boards of direction of these banks.

Other criticisms have concerned the effectiveness of these agencies in promoting the efficiency of irrigation. ("Efficiency" in this context has to be defined broadly and not be limited to water distribution; rather it should be taken to include economic output, the equity of its distribution, and its sustainability) (Brookshire and Whittington 1993; Easter 1993; Howe and Dixon 1993; Ostrom 1993; Roger et al. 1993).

An important tool available to the international banks is the use of covenants. These are agreements attached to loan documents whereby a borrower agrees, as a condition of a loan, to correct prevailing faults such as those already described. Many feel, as do the writers, that the covenants, although usually well prepared, have not received sufficient follow-up by the banks.

With respect to international water conflicts like that of the Middle East, while as previously noted these are greatly af- fected by political considerations, the international banks and technical-assistance agencies can be faulted for failure to take the initiative to alert world political leaders regarding the many ramifications of these conflicts and the need to foster negotiations among the contending parties. The banks could further point out that once sufficient progress has been achieved in the negotiations, they would be in a position to finance a major portion of the investments required.

Still another criticism is that the banks have been too secretive in withholding internal papers and discussions concerning these important issues.

The international banks have been undergoing changes to take cognizance of these criticisms. In any case, the role of the international banks with respect to the developing countries continues to be of primary importance.

\section{ROLE OF ASCE}

ASCE does have a role to play in all this. First, ASCE should lend its weight toward improving the education of engineers, and through selection and abstraction of literature dealing with I\&D in developing countries.

Second, ASCE should find ways to achieve effective liaison with the national and international agencies providing technical assistance and financing. The aims should be to achieve better coordination and avoidance of duplication and-more importantly to exert pressure to carry out reforms and changes, which, although often politically painful, are essential for progress.

\section{ACKNOWLEDGMENTS}

The writers wish first to thank the reviewers of the paper for their help in clarifying various portions of the text of the paper. The writers, who are members of the Planning and Management of Irrigation and Drainage Systems Committee of the Water Resources Engineering Division, wish also to acknowledge encouragement and support for preparation of this paper that they received from that committee. The same committee is in the process of revising the manual entitled "Principles of Project Formulation for Irrigation and Drainage Projects" issued in 1982 by the Irrigation and Drainage Division, ASCE. The revised manual will have a chapter devoted to the special problems of developing countries. 


\section{APPENDIX. REFERENCES}

Ben-Meir, M. (1989). “Technological and institutional innovation in irrigation." World Bank Tech. Paper No. 94: Establishing Res. Priorities, World Bank, Washington, D.C., 108-112.

Biswas, A. K., ed. (1994). Waters of the Middle East from the Euphrates-Tigris to the Nile. Oxford University Press, Oxford House, Apollo Bunder, Bombay, India.

Brookshire, D. S., and Whittington, D. (1993). "Water resources issues in the developing countries." Water Resour. Res., 29(7), 1883-1888.

Brown, L. (1995). State of the world. W. W. Norton \& Co., New York. Fig. 1-2; Fig. 1-8; chapter 1.

Brown, L. (1997). State of the world. W. W. Norton \& Co., New York, 38.

Brown, L. (1998). State of the world. W. W. Norton \& Co., New York, Chapter 1.

"Country experiences with water resources management-economic, institutional and environmental issues.' (1992). Tech. Paper No. 175, World Bank, Washington, D.C.

Easter, K. W. (1993). "Economic failure plagues developing countries' public irrigation: An assurance problem." Water Resour. Res., 29(7), $1913-1922$.

Falkenmark, M., and Widstrand, C. (1992). "Population and water resources: A delicate balance." Population Bull., 47(3).

"Feeding the world." (1994). IIMI Review, International Irrigation Management Institute, Colombo, Sri Lanka, 8(1), 8.

"Food shortages a real threat, World Bank warns; changes in agricultural production policies urged." (1996). World Bank News, April 25, 5.

Frederiksen, H. D. (1996). "Water crisis in developing world: Misconceptions about solutions." J. Water Resour. Plng. and Mgmt., ASCE, 122(2), 79-87.

Grigg, N. S. (1996). "Management framework for large-scale water problems." J. Water Resour. Plng. and Mgmt., ASCE, 122(4), 296-300.

Howe, C. W., and Dixon, J. A. (1993). "Inefficiencies in water project design and operation in the Third World: An economic perspective." Water Resour. Res., 29(7), 1889-1894.

Huang, J., et al. (1997). China's food economy to the twenty-first century: Supply, demand, and trade. International Food Policy Research Institute, Washington, D.C.
Kirpich, P. Z. (1987). "Developing countries: High tech or innovative management?' J. Profl. Issues in Engrg. Educ. and Pract., ASCE, 113(2), 150-166.

Kirpich, P. Z. (1993). "Holistic approach to irrigation management in developing countries." J. Irrig. and Drain. Engrg., ASCE, 119(2), $323-333$

Melamed, D. (1989). "Technological and institutional innovation in irrigation." World Bank Tech. Paper No. 94: Technol. Developments. The Israeli Experience, World Bank, Washington D.C., 23-36.

Ostrom, E. (1993). "Design principles in long-enduring irrigation institutions." Water Resour. Res., 29(7), 1907-1912.

Pletta, D. H. (1989). "Discussion of 'Developing countries: High tech or innovative management?' by Phillip Z. Kirpich." J. Profl. Issues in Engrg. Educ. and Pract., ASCE, 115(2), 74-76.

Plusquellec, H., et al. (1994). "Modern water control in irrigation; concepts, issues and applications." World Bank Tech. Paper No. 246 , World Bank, Washington, D.C., ix and xi.

Postel, S. (1996). "Forging a sustainable water strategy." State of the world, Lester R. Brown, ed., W. W. Norton \& Co., New York, 40-59.

Postel, S., Daily, G., and Ehrlicj, P. (1996). "Human appropriation of renewable fresh water." Sci., 271 (Feb. 9), 785-788.

Roger, P., et al. (1993). "Water resources planning in a strategic context: Linking the water sector to the national economy." Water Resour. Res., 29(7), 1895-1906.

Sne, M. (1989). "Technological and institutional innovation in irrigation.' World Bank Tech. Paper No. 94: The Role of Extension in Irrig., World Bank, Washington, D.C., 116-127.

"User organizations for sustainable water services." (1997). Tech. Paper No. 354, World Bank, Washington, D.C., 18.6.

Van Tuijl, W. A. (1993). "Improving water use in agriculture; experiences in the Middle East and North Africa." World Bank Tech. Paper No. 201, World Bank, Washington, D.C.

Wade, J. S., et al. (1994). "Comparative analysis of the Florida Everglades and the South American Pantanal." Proc., Interamerican Dialogue for Water Mgmt., South Florida Water Management District, Miami, 31-70.

World development report 1995. (1997). World Bank, Washington, D.C., Table 1. 